\title{
Size distribution of fullerenol nanoparticles in cell culture medium and their influence on antioxidative enzymes in Chinese hamster ovary cells
}

\author{
Branislava U. Srdjenovic ${ }^{1}$, Marija N. Slavić ${ }^{2}$, Karmen M. Stankov ${ }^{3}$, Nebojša V. Kladar $^{1}$, Danica S. Jović ${ }^{4}$, \\ Mariana N. Seke ${ }^{5}$, Višnja V. Bogdanović ${ }^{6}$ \\ ${ }^{1}$ University of Novi Sad, Faculty of Medicine, Department of Pharmacy, Novi Sad, Serbia \\ ${ }^{2}$ Institute for Biological Research "Siniša Stanković", Belgrade, Serbia \\ ${ }^{3}$ University of Novi Sad, Faculty of Medicine, Clinical Center of Vojvodina, Novi Sad, Serbia \\ ${ }^{4}$ University of Novi Sad, Faculty of Science, Department of Chemistry, Biochemistry and Environmental Protection, Novi \\ Sad, Serbia \\ ${ }^{5}$ University of Belgrade, Vinča Institute of Nuclear Science, Belgrade, Serbia \\ ${ }^{6}$ Institute of Oncology, Department for Experimental Oncology, Sremska Kamenica, Serbia
}

\begin{abstract}
Fullerenol $\left(\mathrm{C}_{60}(\mathrm{OH})_{24}\right)$ nanoparticles (FNP) have a significant role in biomedical research due to their numerous biological activities, some of which have cytoprotective and antioxidative properties. The aim of this study was to measure distribution of fullerenol nanoparticles and zeta potential in cell medium RPMI 1640 with $10 \%$ fetal bovine serum (FBS) and to investigate the influence of FNP on Chinese hamster ovary cells (CHO-K1) survival, as well as to determine the activity of three antioxidative enzymes: superoxide-dismutase, glutathione-reductase and glutathione-S-transferase in mitomycin C-treated cell line. Our investigation implies that FNP, as a strong antioxidant, influences the cellular redox state and enzyme activities and thus may reduce cell proliferation, which confirms that FNP could be exploited for its use as a cytoprotective agent.
\end{abstract}

Keywords: fullerenol, mytomocine $\mathrm{C}$, antioxidative enzyme, $\mathrm{CHO}$ K1 cell line.

\section{SCIENTIFIC PAPER}

UDC 615:616-085:547

Hem. Ind. 69 (4) 425-431 (2015)

doi: 10.2298/HEMIND131218054S

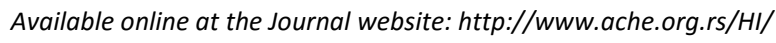

With the rapid development of nanotechnology, many kinds of nanomaterials have been and are being used in fields of industry and scientific researches. A wide range of engineered nanoparticles, ranging from 1-100 nm, have been proposed to be used in nanomedicine due to their unique physical and chemical characteristics. Fullerenols are polyhydroxylated fullerenes $\mathrm{C}_{60}(\mathrm{OH})_{x}$ (between $2>x<44$ ). Fullerenol $\mathrm{C}_{60}(\mathrm{OH})_{24}$ has a diameter of approximately $1 \mathrm{~nm}$ with symmetrically arranged hydroxyl groups on the $\mathrm{C}_{60}$ sphere [1]. Fullerenol dissolved in water forms polyanion nanoparticles of size mostly between 3 and $100 \mathrm{~nm}[2,3]$. Polyhydroxylated fullerenes, including $\mathrm{C}_{60}(\mathrm{OH})_{24}$, have demonstrated high antioxidative activity in many chemical, in vivo and in vitro studies [4-7]. Mrdjanovic et al. confirmed the antigenotoxic effect of FNP on mitomycin-damaged $\mathrm{CHO}-\mathrm{K} 1$ cells [8]. In vitro and in vivo studies have proved fullerenol's tissue-protective effect in irradiated human erythroleukemia cell line K562 and organs of rats, due to its antioxidative and radical scavenging activity $[9,10]$. Results of studies on healthy and tumor-bearing rats, treated with a single high dose

Correspondence: B. Srdjenovic, Department of Pharmacy, Faculty of Medicine, University of Novi Sad, Hajduk Veljkova 3, 21000 Novi Sad, Serbia.

E-mail: srdjbr@yahoo.com

Paper received: 18 December, 2013

Paper accepted: 3 July, 2014 of doxorubicin (DOX), imply the potential tissue-protective role of FNP [11-18].

Internalization of nanoparticles into live cells is closely related to their potential application, function and cytotoxicity. It is known that cellular uptake and the processes of cellular delivery are influenced by various factors, such as: physicochemical properties of nanoparticles (chemical composition, size, shape and surface charge), concentration of nanoparticles, incubation time, the type of cells, etc. [19].

Mitomycin $\mathrm{C}(\mathrm{MMC})$ is an antitumor quinone that undergoes reductive metabolism to generate reactive electrophilic species, which can then alkylate cellular nucleophiles. It also acts as a DNA cross-linking agent [20].

The aim of this study was to measure distribution of FNP by volume and number, as well as zeta potential of particles, in aqueous solution and in RPMI 1640 with $10 \%$ FBS in dark on $37{ }^{\circ} \mathrm{C}$ during $24 \mathrm{~h}$, which are basically used to treat the particles in cell culture. Based on the above mentioned fact concerning numerous biological activities of FNP, our additional goal was to test in vitro influence of FNP on cell's survival and activity of three antioxidative enzymes: total superoxide-dismutase (SOD), glutathione-reductase (GR) and glutathione-S-transferase (GST), in both, mitomycin C-treated CHO$-\mathrm{K} 1$ cells and control untreated groups of $\mathrm{CHO}-\mathrm{K} 1$ cell line. 


\section{MATERIALS AND METHODS}

\section{Fullerenol nanoparticle synthesis}

Fullerenol $\mathrm{C}_{60}(\mathrm{OH})_{24}$ was synthesized in alkaline media by complete substitution of bromine atoms from $\mathrm{C}_{60} \mathrm{Br}_{24}$. Briefly, the polybromine derivative $\mathrm{C}_{60} \mathrm{Br}_{24}$ was synthesized through catalytical $\left(\mathrm{FeBr}_{3}\right)$ reaction of $\mathrm{C}_{60}$ in $\mathrm{Br}_{2}$ [21]. $50 \mathrm{mg}$ of $\mathrm{C}_{60} \mathrm{Br}_{24}$ was mixed in $5 \mathrm{ml}$ of $\mathrm{NaOH} \mathrm{pH}$ 10 for $2 \mathrm{~h}$ at room temperature. After the reaction was completed, the solvent was evaporated at $40{ }^{\circ} \mathrm{C}$, and the mixture was rinsed five times with $10 \mathrm{ml}$ portions of $80 \%$ ethanol. The aqueous solution of fullerenol (20 ml) with residual amounts of $\mathrm{NaOH}$ and $\mathrm{NaBr}$ was applied on the top of the combined ion-exchange resin DOWEX MB50 QC121815 R1 (20 g) and eluted with demineralized water until discoloration. The solution of fullerenol $(\mathrm{pH}$ 7) was evaporated under low pressure; a dark brown powder substance remained. Analysis: FTIR $\mathrm{C}_{60}(\mathrm{OH})_{24}: 3427,1627,1419,1080 \mathrm{~cm}^{-1} ;{ }^{13} \mathrm{C}-\mathrm{NMR}\left(\mathrm{D}_{2} \mathrm{O}\right)$ reaction mixture: singlet peaks at $\delta 77.7 \mathrm{ppm}$ and multiplet at $\delta 140 \mathrm{ppm},{ }^{13} \mathrm{C}-\mathrm{NMR}\left(\mathrm{D}_{2} \mathrm{O}\right) \mathrm{C}_{60}(\mathrm{OH})_{24}$ : singlet peaks $\delta 169.47 \mathrm{ppm}$ and multiplet peak $\delta$ 160-110 ppm; MALDI (matrix $\alpha$-cyano-4-hydroxycinnamic acid) $(\mathrm{m} / \mathrm{z}): 720\left(\mathrm{C}_{60}{ }^{+}\right), 721 \quad\left(\mathrm{C}_{60} \mathrm{H}^{+}\right), 722 \quad\left(\mathrm{C}_{60} \mathrm{H}_{2}{ }^{+}\right), 737$ $\left(\mathrm{C}_{60}(\mathrm{OH})^{+}\right), \quad 808\left(\mathrm{C}_{60}(\mathrm{OH})_{5}^{+}\right), 839 \quad\left(\mathrm{C}_{60}(\mathrm{OH})_{7}^{+}\right), \quad 856$ $\left(\mathrm{C}_{60}(\mathrm{OH})_{8}^{+}\right), 1009\left(\mathrm{C}_{60}(\mathrm{OH})_{17}{ }^{+}\right), 1026\left(\mathrm{C}_{60}(\mathrm{OH})_{18}{ }^{+}\right)$and minor peak $1128\left(\mathrm{C}_{60}(\mathrm{OH})_{24}{ }^{+}\right)$; DTG, DTA, TG reveal two thermal changes, in temperature of $120-395{ }^{\circ} \mathrm{C}$, corresponding to the loss of mass of $35.7 \%(23.7 \mathrm{OH}$ groups) and at the temperature of $430{ }^{\circ} \mathrm{C}$ loss of mass was $64.3 \%$ (this was the temperature of sublimation of $\mathrm{C}_{60}$ ). Elementary analysis of fullerenol provided the following: C, $63.00 \%$;, $2.00 \%$ calc.: C, 63.83\%; H, 2.13\%.

\section{Size distribution of nanoparticles}

In order to obtain results for distribution of particles by volume and number, as well as zeta potential of particles, high performance analyzer Zetasizer Nano ZS (Malvern Instruments) was used. Prior to measurement, samples were tempered at $37{ }^{\circ} \mathrm{C}$ for $24 \mathrm{~h}$ and stored in the dark.

\section{Scanning electron microscopy (SEM)}

Scanning electron microscopy (SEM) was performed with a JEOL JSM 6460 LV scanning microscope (300000x magnification). The $10 \mathrm{ppm}$ aqueous solution of fullerenol was placed on a conductive carbon tape, evaporated under reduced pressure and covered with a thin gold layer about $5 \mathrm{~nm}$.

\section{Cell line treatment}

All the experiments were performed on Chinese hamster ovary cell line CHO-K1, ATCC CCL61 (American Type Culture Collection Catalogue of Cell Lines and Hybridomas, $6^{\text {th }}$ ed., 1988). CHO-K1 cells were cultured as a tightly flask-bonded monolayer in RPMI 1640 med- ium (Sigma), supplemented with 10\% FCS (Veterinary institute Novi Sad, NIVNS), 2 mM L-glutamine, penicillin $(100 \mathrm{~J} / \mathrm{mL})$ and streptomycin $(100 \mu \mathrm{g} / \mathrm{mL}$, Galenika $)$ at $37{ }^{\circ} \mathrm{C}$ in fully humified atmosphere with $5 \% \mathrm{CO}_{2}$. Single-cell suspension was obtained with $0.25 \%$ trypsin or trypsin in EDTA (Sigma). Cells were passaged twice a week in concentration of 50000-100000 cells $/ \mathrm{ml}$.

CHO-K1 sample cells were plated in sterile cultivation plates (Costar, 6 well) in concentration of 200000/ml and treated as follows:

Control - untreated cells

MMC - mitomycin C $0.1 \mu \mathrm{g} / \mathrm{ml}$

F1 - FNP $0.025 \mathrm{mg} / \mathrm{ml}$

$\mathrm{F} 3-\mathrm{FNP} 0.125 \mathrm{mg} / \mathrm{ml}$

$\mathrm{F} 1+\mathrm{MMC}-\mathrm{FNP} 0.025 \mathrm{mg} / \mathrm{ml} 30 \mathrm{~min}$ before MMC $0.1 \mu \mathrm{g} / \mathrm{ml}$

$\mathrm{F} 3+\mathrm{MMC}-\mathrm{FNP} 0.125 \mathrm{mg} / \mathrm{ml} 30 \mathrm{~min}$ before MMC $0.1 \mu \mathrm{g} / \mathrm{ml}$.

FNP was dissolved in bi-distilled water and added in the cell culture in two final concentrations: 0.025 and $0.125 \mathrm{mg} / \mathrm{ml}$ in a 3- and 24-hour treatment.

Mitomycin C was dissolved in distilled water and added in cell culture samples in final concentration of $0.1 \mu \mathrm{g} / \mathrm{ml}$ in a 3- and 24-hour treatment.

In FNP pretreated samples, FNP was added half an hour before MMC.

Dye exclusion test (DET) with Trypan blue was used to monitor the cell survival [22]. The DET test was performed by mixing $50 \mu$ of cell suspension with 200 $\mu \mathrm{l}$ of $0.1 \%$ Trypan blue solution in $0.9 \% \mathrm{NaCl}$. After 2 min of incubation at a room temperature, the number of viable cells (unstained cells) was determined using a Burker-Turk hemocytometer.

Survival rate was calculated according to formula:

Survival rate $(\%)=100 \times($ Total number of viable cells in experimental group / Total number of viable cells in control group)

All enzyme activity assays were performed in cytosolic cell fraction, in supernatant obtained by ultrasonication (Soniprep $150 \mathrm{MSE}$ ) (10 $\mathrm{min}$ at 10000 rpm at $4{ }^{\circ} \mathrm{C}$ ) and kept at $-80{ }^{\circ} \mathrm{C}$. All spectrophotometric measurements were carried out in triplicates (Agilent $8453 \mathrm{UV} / \mathrm{Vis}$ spectrophotometer with thermostatted multicell position sample system).

\section{Superoxide dismutase assay}

Total ( $\mathrm{Cu}-\mathrm{Zn}$ and $\mathrm{Mn}$ ) superoxide dismutase (SOD) activity measuring method was based on the ability of superoxide dismutase to inhibit the auto-oxidation of epinephrine [23]. One unit of activity was defined as the amount of enzyme necessary to decrease by $50 \%$ the rate of adrenalin auto-oxidation at $\mathrm{pH} 10.2$ and 480 $\mathrm{nm}$. The results were expressed as $\mathrm{U} / 10^{6}$ of cells. 


\section{Glutathione reductase assay}

Glutathione reductase (GR) was determined measuring the reduction rate of oxidized glutathione with $\mathrm{NADPH}$ as suitable enzyme substrate at $340 \mathrm{~nm}$ [24]. Activity of GR was defined as nmol of $\mathrm{NADPH} / \mathrm{min}$ per $10^{6}$ of cells.

\section{Glutathione-S-transferase assay}

Glutathione-S-transferase (GST) was based on conjugation of $-\mathrm{SH}$ group of reduced glutathione with 1-chloro-2,4-dinitrobenzene (CDNB) [24]. Absorbance of the conjugate CDNB-glutathione was measured at $340 \mathrm{~nm}$. Activity of GST was expressed as $\mathrm{nmol}$ of CDNB-glutathione conjugate/min per $10^{6}$ of cells.

\section{Statistical analysis}

The data were analyzed by Multivariate analysis of variance (MANOVA) followed by Duncan test at 0.05 significance level to compare the means using SPSS 13.0 for Windows.

\section{RESULTS AND DISCUSSION}

Results for size distribution of particles by volume (Fig. 1a) put an emphasis on inhomogeneity of the analyzed samples. In all samples can be noticed the presence of particles of dimensions within 2-30 nm, with the maximum at $5 \mathrm{~nm}$. Fullerenol nanoparticles in aqueous solution are mostly within $2-8 \mathrm{~nm}$, while in samples containing fetal bovine serum size varies within 2-30 nm. Addition of FNP in the cell culture medium with $10 \%$ FBS has not influenced the size distribution of nanoparticles by volume.

Figure $1 \mathrm{~b}$ presents nanoparticle's size distribution by number in which particles are classified into a family within 2-9 $\mathrm{nm}$, with the maximum at approx. $5 \mathrm{~nm}$. It can be concluded that addition of FNP in the culture medium with $10 \%$ FBS has not induced changes in the size of particles.

In Figure 2, SEM image of the fullerenol nanoparticles studied in this work shows the particles size from $30-80 \mathrm{~nm}$. These findings are in accordance with DLS and AFM measurements conducted before [25].

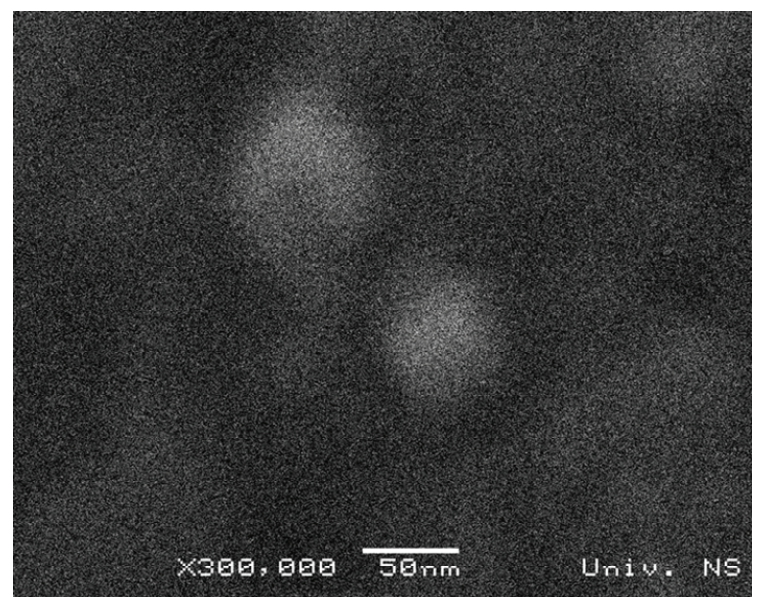

Figure 2. SEM image of film resulted from a $10 \mathrm{ppm}$ aqueous solution of fullerenol.

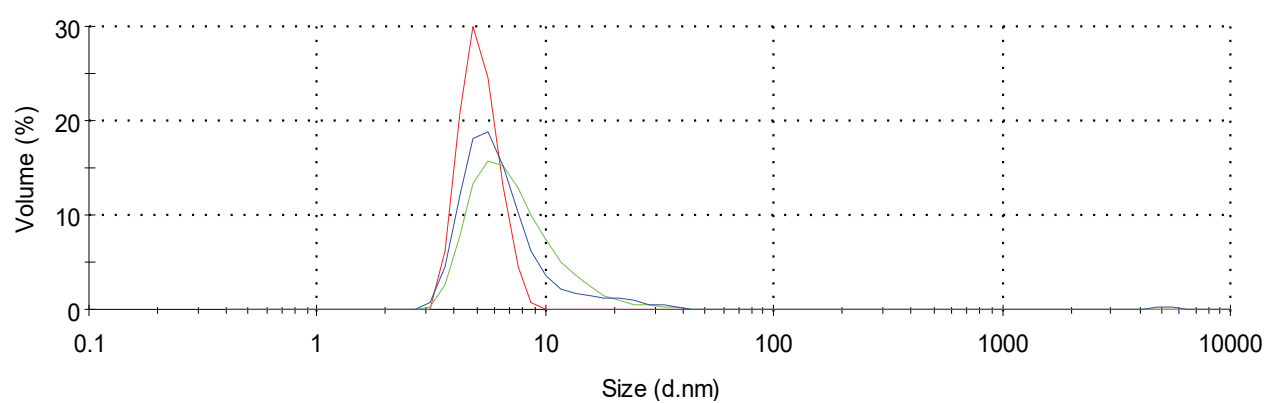

(a)

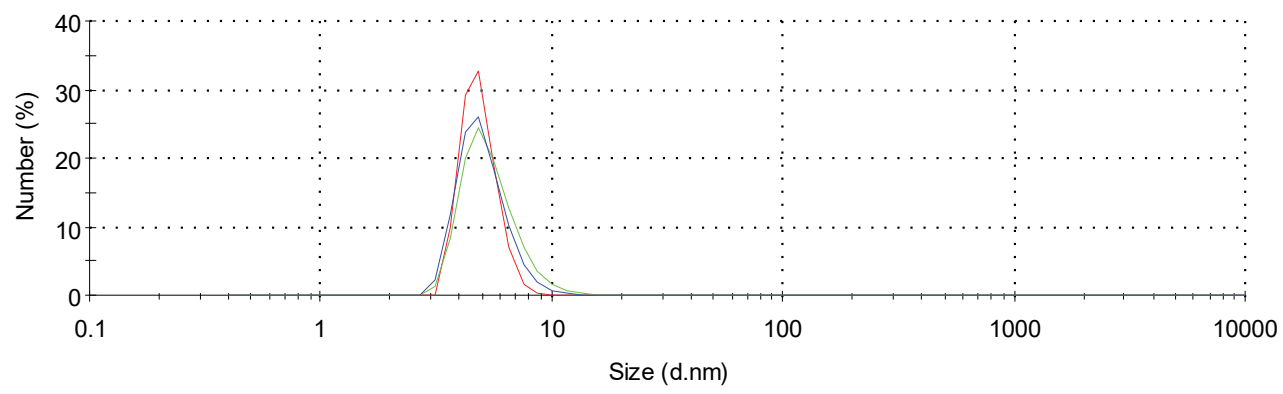

(b)

Figure 1. Size distribution of nanoparticles a) by volume and b) by number, in the following samples: cell culture medium RPMI 1640 $+10 \%$ FBS (green); aqueous solution of fullerenol (red); and fullerenol in cell culture medium RPMI $1640+10 \%$ FBS (blue), after incubation for $24 \mathrm{~h}$ at $37{ }^{\circ} \mathrm{C}$ in the dark. 
Table 1 shows the results of measurements for $\zeta$-potential of the following systems: RPMI $1640+10 \%$ FBS, aqueous solution of FNP pH 6, and aqueous solution of FNP in RPMI $+10 \%$ FBS (incubated for $24 \mathrm{~h}$ at $37{ }^{\circ} \mathrm{C}$ in the dark). $\zeta$-potential of polyanionic fullerenol nanoparticles at $\mathrm{pH} 6$ is $-58 \mathrm{mV}$. After addition of FNP in the cell culture medium RPMI with $10 \% \mathrm{FBS}, \zeta$-potential of the medium slightly changed from -3.6 to -7.9 $\mathrm{mV} ; \zeta$-potential of nanoparticles solution changed from -58 to $-7.9 \mathrm{mV}$.

Table 1. $\zeta$-potential of the following systems: RPMI $1640+$ $10 \%$ FBS, aqueous solution of FNP and aqueous solution of FNP in RPMI + 10\% FBS (incubated for $24 \mathrm{~h}$ at $37{ }^{\circ} \mathrm{C}$ in the dark)

\begin{tabular}{lc}
\hline Sample & $\zeta$-potential, $\mathrm{mV}$ \\
\hline RPMI $1640+10 \%$ FBS & -3.6 \\
Aqueous solution of FNP: FNPaq, pH 6 & -58 \\
FNPaq + RPMI + 10\% FBS & -7.9 \\
\hline
\end{tabular}

It has been confirmed that particles' size has an important role on their adhesion to and interaction with biological cells. It is also known that the size of FNP is an important property in the toxicity analysis, since nanoparticles have a tendency to form agglomerates, which may behave differently from a single nanoparticle. Also, the presence of proteins in the culture medium can change the nanoparticles agglomeration and influence the cellular response. Nanoparticles, which are partially covered by proteins in body fluids, can change reactivity, charge and hydrophobicity [26]. It is also well-known that FNP can pass through the plasma membrane and manifest its biological effects inside the cell [27].

We can conclude that investigated FNP does not have a tendency to form agglomerates, based on the results for distribution of particles by volume and number obtained in our experiment, as well as according to the measurements for $\zeta$-potential after incubation in cell medium. Furthermore, the presence of proteins in the culture medium does not induce significant changes in terms of nanoparticles agglomeration. Results of AFM analysis of FNP in the cell culture medium supplemented with $20 \%$ of FBS [25] revealed that FNP (which in water form aggregates of approx. 90 $\mathrm{nm}$ ) forms a stable and homogenous solution that mostly consists of two dimer particles of $90 \mathrm{~nm}$ associated with one smaller nanoparticle of about $40 \mathrm{~nm}$, which was assumed to be a protein from the FBS.

Results obtained in our experiment show that addition of FNP in the cell culture medium with $10 \%$ FBS does not influence the size distribution of nanoparticles and does not induce formation of such a large particle, but causes reduction in $\zeta$-potential of nanoparticles (from -58 to $-7.9 \mathrm{mV}$ ). Monitoring of $\zeta$-potential is particularly important due to possible interactions that can be favored as a result of change in particles' surface charge.

In vitro effects of FNP on the induction of cellular antioxidative capacity, actually on the increased activity of enzymes of the antioxidative system in the cells exposed to oxidative stress, are cell type- and dose-dependent [9]. Results showed that FNP did not induce genotoxic effect, on the contrary antigenotoxic effects of FNP were confirmed in the experiment done on MMC-damaged $\mathrm{CHO}-\mathrm{K} 1$ cells in concentration of 11.0-221.6 $\mu \mathrm{M}$ [8].

Our present investigation has shown that FNP in both examined concentrations moderates the activities of oxidative enzymes SOD and GR in comparison to the control, which implies that it undoubtedly enters the cells and participates in cell metabolism (Fig. 3). This mild change in enzyme activity does not affect the survival of cells.

Possible mechanisms responsible for the increased activity of SOD in CHO-K1 cells treated with FNP may be explained by the fact that fullerenol acts as NO-scavenger, which prevents superoxide consumption in the reaction of peroxynitrite anion formation, simultaneously increasing $\mathrm{O}^{2-}$ concentration and SOD activity as a consequence of superoxide excess $[9,28]$.

Depending on the applied dose, the activity of enzyme GR was both, increased and reduced. The increase in activity of GR indicates the reduced cellular milieu that enables cells to efficiently scavenge free radicals, formed as a result of FNP participating in cellular metabolism, which can clarify the absence of significant influence of FNP on cell survival. Reduced activity of GR in a 3-hour experiment with FNP of higher concentration can be explained by inactivation of this enzyme due to increased level of free radicals, while results of 24-hour experiment suggest the compensatory upregulation of mRNK and reactivation of mentioned enzymes [13].

Fullerenol expressed no influence on GST activity, since it probably did not participate in detoxification of FNP. Furthermore, FNP did not induce formation of oxidative damage products to such extent to activate GST. Study conducted on the freshwater zebrafish exposed to fullerenol $\left(\mathrm{C}_{60}(\mathrm{OH})_{18}-22(\mathrm{OK} 4)\right)$ analyzed oxidative stress responses on fish brain. They also did not detect any statistically significant changes in GST activity or TBARS level [29].

Application of mitomycin C significantly increases the activity of all three enzymes, which presents the antioxidative response of cells to the applied agent. High activity of SOD in groups pretreated with FNP in comparison with the group treated only with $\mathrm{MMC}$ could be explained by the fact that fullerenol nanoparticles already act as NO-scavenger which concomi- 


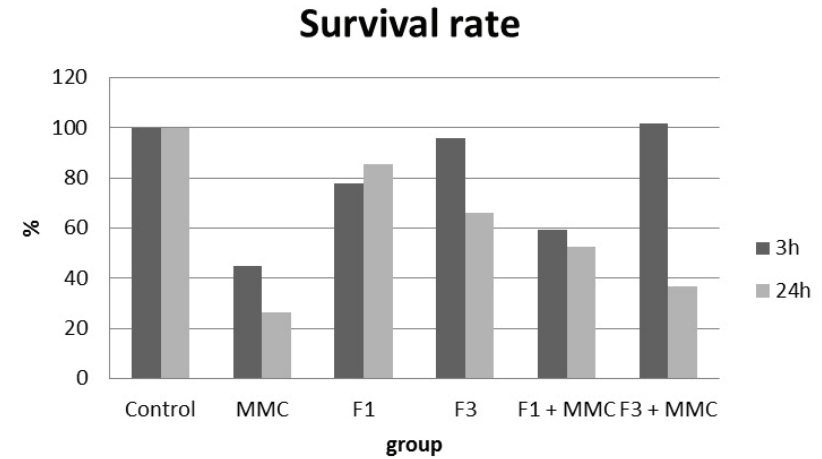

GR

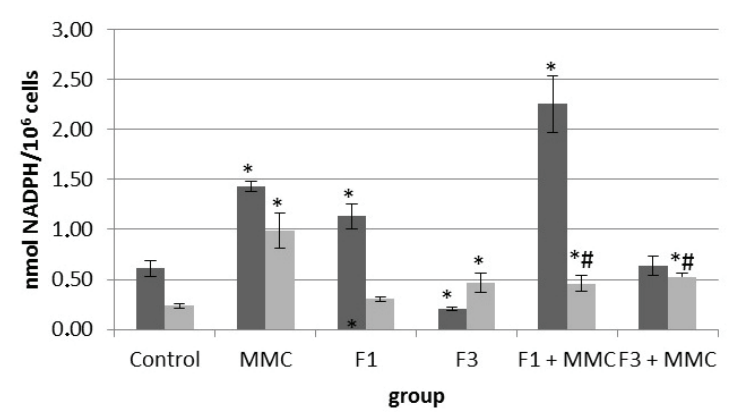

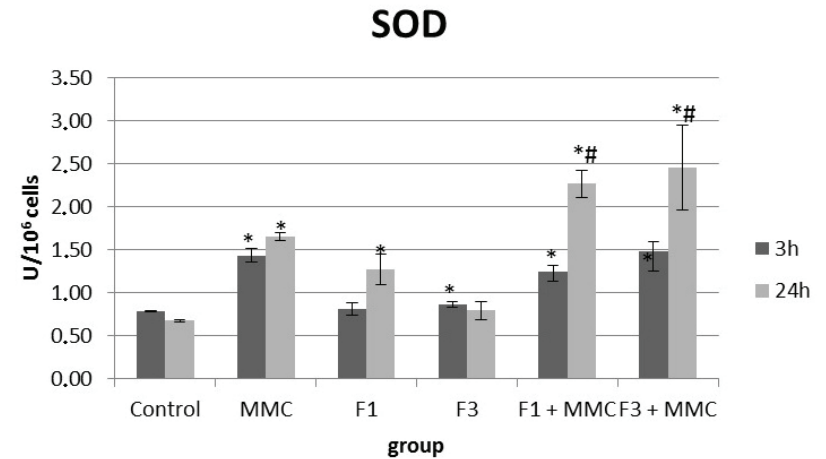

GST

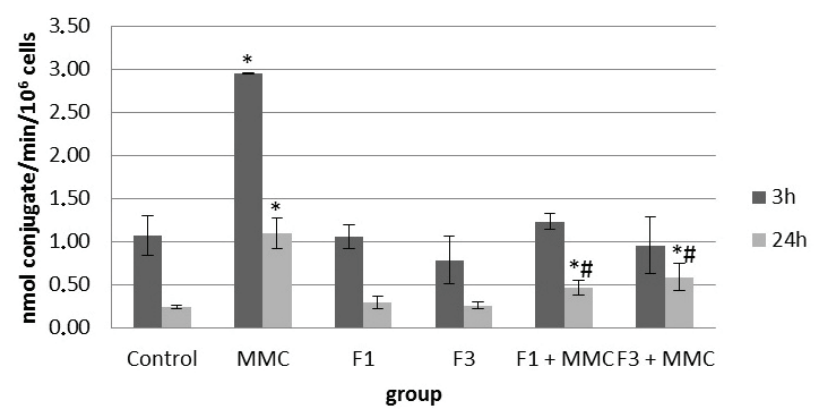

Figure 3. Effect of FNP and MMC on cells survival rate and activity of enzymes SOD, GR, GST in CHO-K1 cell line 3 and 24 h after the treatment. Control - untreated cells; MMC - mitomycin C $0.1 \mu \mathrm{g} / \mathrm{ml} ; F 1-F N P 0.025 \mathrm{mg} / \mathrm{ml} ; \mathrm{F} 3-F N P 0.125 \mathrm{mg} / \mathrm{ml} ; \mathrm{F} 1+\mathrm{MMC}-\mathrm{FNP}$ $0.025 \mathrm{mg} / \mathrm{ml} 30 \mathrm{~min}$ before mitomycin $C 0.1 \mu \mathrm{g} / \mathrm{ml} ; \mathrm{F} 3+$ MMC - FNP $0.125 \mathrm{mg} / \mathrm{ml} 30 \mathrm{~min}$ before mitomycin C $0.1 \mu \mathrm{g} / \mathrm{ml} ;$

$*-p<0.05$ vs. control group; \#-p<0.05 vs. group treated only with mitomycin $C$.

tantly increases the $\mathrm{O}^{2-}$ concentration and SOD activity. Addition of MMC leads to more superoxide production and additional influence on the balance between NO and $\mathrm{O}^{2-}$ in cells, and consequently high SOD activity.

Pretreatment with the lower concentration of FNP notably increases the activity of GR even in comparison to mitomycin C. This may happen because FNP in such a low concentration does not exhibit potent antioxidative potential, where $24 \mathrm{~h}$ after pretreatment the activity of this enzyme was yet to reach the control level, but still was statistically significantly lower than the values in MMC groups. Survival rate of pretreated cells was significantly higher in comparison to those treated only with $\mathrm{MMC}$, which confirms the protective properties of FNP in the range of used concentrations in MMC-damaged CHO-K1 cells [8].

In acute phase, the higher concentration of FNP completely neutralizes the consequences of MMC treatment and normalizes the activity of GR, which was reflected also on the survival percentage of the cells (101.74\%). Although the activity of GR after $24 \mathrm{~h}$ was increased in comparison to control, the survival rate was significantly higher than survival rate in MMC treated group. The results of GST activity also point out the protective effects of FNP since pretreatment with FNP significantly neutralizes the influence of $M M C$ on the activity of this enzyme. These findings are in accordance with the study conducted A549 cells where pretreatment with $\mathrm{C}_{60}(\mathrm{OH})_{24}$ attenuated hydrogen peroxide-induced apoptotic cell death by induction of phase II detoxifying enzymes [30].

As previous works concluded, polyhydroxylated fullerenes, as strong antioxidants, influence the cellular redox state and thus could reduce cell proliferation, which could be exploited for the use of fullerenol as a cytoprotective agent $[4,31,32]$.

\section{CONCLUSION}

In summary, the present results demonstrate that polyanion fullerenol nanoparticles reduce mitomycin C-induced oxidative stress in dose- and time-dependent manner, and therefore possess beneficial effects on preventing drug toxicity in CHO-K1 cells. Applied alone, fullerenol nanoparticles influence the cell metabolism moderately and not in such a manner to induce any severe irreversible changes that would consequently lead to the cell death.

\section{Acknowledgment}

This work is supported by The Ministry of Education, Science and Technological Development of the Republic of Serbia, project No. III45005 and the Provincial Secretariat for Science and Technological 
Development of Vojvodina (grant number 114-451-2056/2011-01).

\section{REFERENCES}

[1] S. Wilson, D. Schuster, M. Maggini M. Prato, R. Taylor, in K.M. Kadish, R.S. Ruoff (Eds.), Organic chemistry of fullerenes, Wiley-Interscience, New York, 2000, pp. 91$-177$.

[2] B. Vileno, P.R. Marcox, M. Lekka, A. Sienkiewicz, T. Fehre, L. Forro, Spectroscopic and physical properties of a highly derivatized $\mathrm{C}_{60}$ fullerol, Adv. Funct. Mater. 16 (2006) 120-128.

[3] J.A. Brant, C.O. Robichaund, M. Wiesner, Fullerol cluster formation in aqueous solutions: Implications for environmental release, J. Colloid Interface Sci. 314 (2007) 281-288.

[4] G. Bogdanovic, V. Kojic, A. Djordjevic, J. CanadanovicBrunet, M. Vojinovic-Miloradov, V.V. Baltic, Modulating activity of fullerenol $\mathrm{C}_{60}(\mathrm{OH})_{22}$ on doxorubicin-induced cytotoxicity, Toxicol. In Vitro 18 (2004) 629-637.

[5] A. Djordjevic, J. Canadanovic-Brunet, M. Vojinovic-Miloradov, G. Bogdanovic, Antioxidant properties and hypothetical radical mechanism of fullerenol $\mathrm{C}_{60}(\mathrm{OH})_{24}$, Oxid. Commun. 27 (2005) 213-218.

[6] J. Grebowski, P. Kazmierska, A. Krokosz, Fullerenols as a New Therapeutic Approach in Nanomedicine, Biomed. Res. Int. (2013), DOI: 10.1155/2013/751913.

[7] J.J. Yin, F. Lao, P.P. Fu, W.G. Wamer, Y. Zhao, P.C. Wang, Y. Qiu, B. Sun, G. Xing, J. Dong, X-J. Liang, C. Chen, The scavenging of reactive oxygen species and the potential for cell protection by functionalized fullerene materials, Biomaterials 30 (2009) 611-621.

[8] J. Mrđanović, S. Šolajić, V. Bogdanović, K. Stankov, G. Bogdanović, A. Djordjevic, Effects of fullerenol $\mathrm{C}_{60}(\mathrm{OH})_{24}$ on the frequency of micronuclei and chromosome aberrations in CHO-K1 cells, Mutat. Res: Genet. Toxicol. Environ. Mutagen 680 (2009) 25-30.

[9] V. Bogdanović, K. Stankov, I. Ičević, D. Žikić, A. Nikolić, S. Šolajić, A. Djordjevic, G. Bogdanović, Fullerenol $\mathrm{C}_{60}(\mathrm{OH})_{24}$ effects on antioxidative enzymes activity in irradiated human erythroleukemia cell line, J. Radiat. Res. 49 (2008) 321-327.

[10] S. Trajković, S. Dobrić, V. Jačević, V. Dragojević-Simić, Z. Milovanović, A. Djordjevic, Tissue protective effects of fullerenol $\mathrm{C}_{60}(\mathrm{OH})_{24}$ and amifostine in irradiated rats, Colloids Surfaces, B 58 (2007) 39-43.

[11] V. Djordjevic-Milic, K. Stankov, R. Injac, A. Djordjevic, B. Srdjenovic, B. Govedarica, N. Radic, V. Dragojevic-Simic, B. Strukelj, Activity of antioxidative enzymes in erythrocytes after a single dose administration of doxorubicin in rats pretreated with fullerenol $\mathrm{C}_{60}(\mathrm{OH})_{24}$, Toxicol. Mech. Methods 19 (2009) 24-28.

[12] V. Milic-Torres, B. Srdjenovic, V. Jacevic,V. Dragojevic-Simic, A. Djordjevic, A.L. Simplício, Fullerenol $\mathrm{C}_{60}(\mathrm{OH})_{24}$ prevents doxorubicin-induced acute cardiotoxicity in rats, Pharmacol. Rep. 62 (2010) 707-718.

[13] B. Srdjenovic, V. Milic-Torres, N. Grujic, K. Stankov, A. Djordjevic, V. Vasovic, Antioxidant properties of fulle- renol $\mathrm{C}_{60}(\mathrm{OH})_{24}$ in rat kidneys, testes, and lungs treated with doxorubicin, Toxicol. Mech. Meth. 20 (2010) 298$-305$.

[14] I. Icevic, S. Vukmirovic, B. Srdjenovic, J. Sudji, A. Djordjevic, R. Injac, V. Vasović, Protective effects of orally applied fullerenol nanoparticles in rats after a single dose of doxorubicin, Hem. Ind. 65 (2011) 329-337.

[15] R. Injac, M. Perse, N. Obermajer, V. Djordjevic-Milic, M. Prijatelj, A. Djordjevic, A. Cerar, B. Strukelj, Potential hepatoprotective effects of fullerenol $\mathrm{C}_{60}(\mathrm{OH})_{24}$ in doxorubicin-induced hepatotoxicity in rats with mammary carcinomas, Biomaterials 29 (2008) 3451-3460.

[16] R. Injac, M. Boskovic, M. Perse, E. Koprivec-Furlan, A. Cerar, A. Djordjevic, B. Strukelj, Acute doxorubicin nephrotoxicity in rats with malignant neoplasm can be successfully treated with fullerenol $\mathrm{C}_{60}(\mathrm{OH})_{24}$ via suppression of oxidative stress, Pharmacol. Rep. 60 (2008) 742-749.

[17] R. Injac, N. Radic, B. Govedarica, M. Perse, A. Cerar, A. Djordjevic, B. Strukelj, Acute doxorubicin pulmotoxicity in rats with malignant neoplasm is effectively treated with fullerenol $\mathrm{C}_{60}(\mathrm{OH})_{24}$ trough inhibition of oxidative stress, Pharmacol. Rep. 61 (2009) 335-342.

[18] R. Injac, M. Perse, M. Cerne, N. Potocnik, N. Radic, B. Govedarica, A. Djordjevic, A. Cerar, B. Strukelj, Protective effects of fullerenol $\mathrm{C}_{60}(\mathrm{OH})_{24}$ against doxorubicin-induced cardiotoxicity and hepatotoxicity in rats with colorectal cancer, Biomaterials 30 (2009) 1184$-1196$.

[19] L.Yan, Z. Gu, Y. Zhao, Chemical mechanisms of the toxicological properties of nanomaterials: generation of intracellular reactive oxygen species, Chem. Asian J. 10 (2013) 2342-2353.

[20] D. Siegel, H. Beall, C. Senekowitsch, M. Kasai, H. Arai, N. Gibson, D. Ross, Bioreductive activation of mitomycin C by DT-diaphorase, Biochemistry 31 (1992) 7879-7885.

[21] A. Djordjević, M. Vojinović-Miloradov, N. Petranović, A. Devečerski, D. Lazar, B. Ribar, Catalytic preparation and characterization of $\mathrm{C}_{60} \mathrm{Br}_{24}$, Fullerene Sci. Technol. 6 (1998) 689-694.

[22] M.C. Black, B. Berenbaum, Factors affecting the dye exclusion test for cell viability, Exp. Cell. Res. 3 (1985) 9$-13$.

[23] H.P. Mishra, I. Fridovich, The role of superoxide anion in the autoxidation of epinephrine and a simple assay for superoxide dismutase, J. Biol. Chem. 247 (1972) 3170-3175 .

[24] E. Beutler, Red Cell Metabolism: A Manual of Biochemical Methods, Grune\&Stratton, New York, 1984.

[25] J. Mrđanovic, S. Šolajić, V. Bogdanović, A. Đorđević, G. Bogdanović, R. Injac, Z. Rakočević, Effects of fullerenol nano particles $\mathrm{C}_{60}(\mathrm{OH})_{24}$ on micronuclei and chromosomal aberrations' frequency in peripheral blood lymphocytes, Dig. J. Nanomater. Biostruct. 7 (2012) 673$-386$.

[26] B. Fubini, M. Ghiazza, I. Fenoglio, Physicochemical features of engineered nanoparticles relevant to their toxicity, Nanotoxicology 4 (2010) 347-363. 
[27] J.G. Saathoff, A.O. Inman, X.R. Xia, J.E. Riviere, N.A. Monteiro-Riviere, In vitro toxicity assessment of three hydroxylated fullerenes in human skin cells, Toxicol. In Vitro 25 (2011) 2105-2112.

[28] D. Wink, J. Mitchell, Chemical biology of nitric oxide: Insights into regulatory, cytotoxic and cytoprotective mechanisms of nitric oxide, Free Radic. Biol. Med. 25 (1998) 434-456.

[29] A.M. da Rocha, J.R. Ferreira, D.M. Barros, T.C.B. Pereira, M.R. Bogo, S. Oliveira, V. Geraldo, R.G. Lacerda, A.S. Ferlauto, L.O. Ladeira, M.V.B. Pinheiro, J.M. Monserrat, Gene expression and biochemical responses in brain of zebrafish Danio rerio exposed to organic nanomaterials: Carbon nanotubes (SWCNT) and fullerenol $\left(\mathrm{C}_{60}(\mathrm{OH})_{18}-\right.$
-22(OK4)), Comp. Biochem. Phys., A 165 (2013) 460$-467$.

[30] S. Ye, M. Chen, Y. Jiang, M. Chen, T. Zhou, Y. Wang, Z. Hou, L. Ren, Polyhydroxylated fullerene attenuates oxidative stress-induced apoptosis via a fortifying Nrf2-regulated cellular antioxidant defence system. Int. J. Nanomed. 9 (2014) 2073-2087.

[31] R. Injac, N. Radic, B. Govedarica, A. Djordjevic, B. Strukelj, Bioapplication and activity of fullerenol $\mathrm{C}_{60}(\mathrm{OH})_{24}$, Afr. J. Biotechnol. 7 (2008) 4050-4940.

[32] V.M. Torres, B. Srdjenovic, in: R.F.Verner, C. Benvegnu (Eds.), Handbook on Fullerene: Synthesis, Properties and Applications, Nova Science Publishers, Inc., Hauppauge, 2012, pp. 197-238.

\section{RASPODELA FULERENOLSKIH NANOČESTICA PO VELIČINI U ĆELIJSKOM MEDIJUMU I NJIHOV UTICAJ NA ANTIOKSIDATIVNE ENZIME U OVARIJALNIM ĆELIJAMA KINESKOG HRČKA}

Branislava U. Srdjenovic ${ }^{1}$, Marija N. Slavić ${ }^{2}$, Karmen M. Stankov ${ }^{3}$, Nebojša V. Kladar ${ }^{1}$, Danica S. Jović ${ }^{4}$, Mariana N. Seke $^{5}$, Višnja V. Bogdanović ${ }^{6}$

${ }^{1}$ Univerzitet u Novom Sadu, Medicinski fakultet, Katedra za farmaciju, Novi Sad, Srbija

${ }^{2}$ Institut za biološka istraživanja "Siniša Stanković”, Beograd, Srbija

${ }^{3}$ Univerzitet u Novom Sadu, Medicinski fakultet, Klinički centar Vojvodine, Novi Sad, Srbija

${ }^{4}$ Univerzitet u Novom Sadu, Prirodno-matematički fakultet, Departman za hemiju, biohemiju i zaštitu životne sredine, Novi Sad, Srbija

${ }^{5}$ Univerzitet u Beogradu, Institu za nuklearne nauke „Vinča”, Beograd, Srbija

${ }^{6}$ Institut za onkologiju, Zavod za eksperimentalnu onkologiju, Sremska Kamenica, Srbija

(Naučni rad)

Zahvaljujući širokoj biološkoj aktivnosti, npr. citoprotektivnom i antiksidativnom svojstvu, fulerenol ima značajnu ulogu u biomedicinskim istraživanjima, na šta ukazuju i rezultati brojnih istraživanja. Cilj ovog istraživanja je bio merenje zeta potencijala i raspodele fulerenol nanočestica u medijumu RPMI $1640+10 \%$ FBS (Fetal Bovine Serum), kao i ispitivanje uticaja fulerenola na preživljavanje ćelija i aktivnost tri antioksidativna enzima: superoksid-dismutaze, glutation-reduktaze i glutation-S-transferaze, u mitomicinom C tretiranoj ćelijskoj liniji. Istraživanje je obavljeno na ćelijama jajnika kineskog hrčka CHO-K1 (Chinese Hamster Ovary cells) koristeći DET test (Due Exclusion Test) za brojanje ćelija, kao i set spektrofotometrijskih metoda za određivanje antioksidativne aktivnosti. Ćelije su pre tretmana mitomicinom $\mathrm{C}$ tretirane fulerenolom $\mathrm{u}$ dve različite koncentracije, a potom inkubirane i analizirane nakon 3 i $24 \mathrm{~h}$. Dodavanje fulerenolskih nanočestica u medijum sa $10 \%$ FBS nije izazvalo promene u raspodeli veličina čestica po broju ili

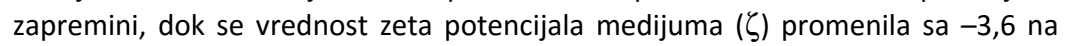
$-7,9 \mathrm{mV}$. Fulerenol ispoljava protektivni efekat na ćelije CHO-K1 koje su tretirane mitomicinom C. Mitomicin C povećava aktivnost sva tri ispitana enzima, dok sam fulerenol u veoma maloj meri utiče na aktivnost pomenutih enzima. Pretretman sa fulerenolom smanjuje stres indukovan mitomicinom $C$ po vremenski i dozno zavisnom obrascu. Naše istraživanje potvrđuje da nanočestice fulerenola utiču na redoks stanje i enzimsku aktivnost ispitivane ćelijske linije, što ukazuje na to da mogu sniziti nivo ćelijske proliferacije i naći primenu kao citoprotektivni agens.
Ključne reči: Fulerenol • Mitomicin C • Antioksidativni enzimi • CHO K1 ćelijska linija 